\title{
Comparative assessment of phytochemical composition, antioxidant and anticholinesterase activities of two Basidiomycota Truffle Fungi from Turkey
}

\author{
Gülsen TEL-ÇAYAN ${ }^{1, *}$, Ebru DEVECİ ${ }^{2}$, Fatih ÇAYAN ${ }^{1}$, Mehmet Emin DURU ${ }^{2}$ \\ Department of Chemistry and Chemical Processing Technologies, Muğla Vocational School, Muğla Sıtkı Koçman University, Muğla, Turkey \\ 2 Department of Chemistry, Faculty of Science, Muğla Sıtkı Koçman University, Muğla, Turkey
}

\begin{abstract}
The aim of the present study was to compare phytochemical composition and biological activities of various extracts of two Basidiomycota truffle collected from Turkey. Analysis of phytochemical compositions in terms of phenolic and fatty acid compositions was determined using HPLC-DAD, GC and GC/MS. Fumaric (10.62, $4.12 \mu \mathrm{g} / \mathrm{g})$ and protocatechuic acids $(2.71,20.50$ $\mu \mathrm{g} / \mathrm{g}$ ) were identified as the major organic and phenolic acids in Chondrogaster pachysporus and Setchelliogaster tenuipes truffles. Linoleic acid (53.03\%) for C. pachysporus and palmitic acid (38.60\%) for S. tenuipes were found to be the most dominant fatty acids. The extracts were also tested for their antioxidant and anticholinesterase activities. As for antioxidant and anticholinesterase activity results, C. pachysporus truffle showed better activity than S. tenuipes. This work presents the first phytochemical study on $C$. pachysporus and $S$. tenuipes truffles and sheds light on their potential usage as the natural source in the food, pharmaceutical, and cosmetic industries.
\end{abstract}

KEYWORDS: Anticholinesterase effect; antioxidant activity; truffle (Basidiomycota); C. pachysporus; S. tenuipes; phenolic compounds.

\section{INTRODUCTION}

Mushrooms are considered as valuable foods in many culture due to their unique flavor [1], taste $[2,3]$, nutritional properties $[4,5]$ and biological activities [6-8].

Truffle species are a group of hypogenous mushroom and consist of two classes: Truffles (Ascomycetes) having sac-like spore producing structures (the ascus; plural asci); The false truffles or truffle-like fungi (Basidiomycetes) containing a typical mushroom fruitbody and less mushroom-like. Most truffle-like fungi form ectomycorrhizae with plant hosts, especially in the families Pinaceae, Cistaceae, Saliaceae, Betulaceae, Fagaceae, and Myrtaceae [9]. Basidiomycetes including to mushroom species of bolete, polypores, shelf fungi, bird's nests, stinkhorns and puffballs, is the most familiar mushroom to humans. Although they are made of different types of fruitbodies, spore production style is common [10].

Truffles have been used as culinary delights for thousands of years and were known by ancient Egypt, Greek, and Roman civilizations [11]. Truffles are the most highly valued, both economically and gastronomically because of their flavor and delicious taste [12]. They are rich in protein (amino acids), minerals, fatty acids, and carbohydrates [13]. In addition to their nutritional properties, truffle species show

Received: 14.06.2017 / Accepted: 16.08.2017

Corresponding Author: Gülsen Tel-Çayan

E-mail: gulsentel@mu.edu.tr; gulsentelcayan@gmail.com

Phone: +90 2522111494

ORCID No: https://orcid.org/0000-0002-1916-7391 biological properties such as antiinflammatory, antioxidant, antimicrobial, antiviral, anti-mutagenic, hepatoprotective and anticancer [11, 14-19].

Due to the nutritional and biological significance of truffle species, investigations about these species have been increased. In this study, we aimed to determine antioxidant and anticholinesterase activities of the hexane, ethyl acetate, methanol, butanol and water extracts of $C$. pachysporus and S. tenuipes truffles spreads under the eucalyptus trees. Also, phenolic compounds were identified by HPLC-DAD and fatty acid compositions were investigated by GC and GC/ MS. According to our literature survey, there is no study about these species. So, this is the first study on chemical composition and biological activities of $C$. pachysporus and S. tenuipes truffles.

\section{RESULTS AND DISCUSSION}

\subsection{Phenolic composition}

Phenolic compounds are secondary metabolites capable of exhibiting antioxidant, antimicrobial, anti-inflammatory and anti-cancer activities [20]. Because of this biological

How to cite this article: Tel-Çayan G, Deveci E, Çayan F, Duru ME. Comparative assessment of phytochemical composition, antioxidant and anticholinesterase activities of two Basidiomycota Truffle Fungi from Turkey. Marmara Pharm J. 2018; 22 (1): 59-65. 
importance of phenolic compounds, in this study, the phenolic profiles of $C$. pachysporus and $S$. tenuipes were investigated in details (Table 1).

Table 1. Composition of phenolic and organic acids in Truffle species ${ }^{a}$

\begin{tabular}{|c|c|c|c|}
\hline Compounds & $\begin{array}{l}\mathrm{RT} \\
(\mathrm{min})\end{array}$ & $\begin{array}{l}\text { C. pachysporus } \\
(\mu \mathrm{g} / \mathrm{g})\end{array}$ & $\begin{array}{l}\text { S. tenuipes } \\
(\mu \mathrm{g} / \mathrm{g})\end{array}$ \\
\hline Gallic acid & 4.37 & nd & $\mathrm{nd}^{\mathrm{b}}$ \\
\hline Fumaric acid & 5.59 & $10.62 \pm 0.002$ & $4.12 \pm 0.002$ \\
\hline Protocatechuic acid & 6.87 & $2.71 \pm 0.001$ & $20.50 \pm 0.002$ \\
\hline Catechin hydrate & 8.46 & $0.89 \pm 0.001$ & nd \\
\hline p-hydroxybenzoic acid & 10.64 & nd & $0.41 \pm 0.001$ \\
\hline $\begin{array}{l}\text { 6,7-dihydroxy } \\
\text { coumarin }\end{array}$ & 11.62 & nd & $0.48 \pm 0.001$ \\
\hline Caffeic acid & 13.13 & $0.08 \pm 0.001$ & $0.11 \pm 0.001$ \\
\hline Vanillin & 14.89 & nd & nd \\
\hline $\begin{array}{l}\text { 2,4-dihydroxy benzoic } \\
\text { acid }\end{array}$ & 15.54 & nd & nd \\
\hline p-coumaric acid & 18.74 & nd & $0.09 \pm 0.001$ \\
\hline Ferulic acid & 19.76 & $0.04 \pm 0.001$ & $0.19 \pm 0.002$ \\
\hline Coumarin & 20.96 & $0.01 \pm 0.001$ & $0.02 \pm 0.001$ \\
\hline $\begin{array}{l}\text { trans-2-hydroxy } \\
\text { cinnamic acid }\end{array}$ & 21.98 & nd & nd \\
\hline Ellagic acid & 22.54 & $0.21 \pm 0.001$ & $0.58 \pm 0.002$ \\
\hline Rosmarinic acid & 23.61 & $0.18 \pm 0.001$ & $0.27 \pm 0.001$ \\
\hline trans-cinnamic acid & 24.52 & $0.24 \pm 0.001$ & $0.12 \pm 0.001$ \\
\hline
\end{tabular}

${ }^{a}$ Values represent the means \pm S.E.M. of three parallel measurements $(p<0.05)$.

${ }^{b}$ nd: Not detected

Phenolic and organic acid compounds (expressed as $\mu \mathrm{g} / \mathrm{g}$ extract) were identified by HPLC-DAD and results are presented in Table 1. Sixteen phenolic compounds namely, gallic acid, fumaric acid, protocatechuic acid, catechin hydrate, p-hydroxybenzoic acid, 6,7-dihydroxy coumarin, caffeic acid, vanillin, 2,4-dihydroxybenzoic acid, p-coumaric acid, ferulic acid, coumarin, trans-2-hydroxycinnamic acid, ellagic acid, rosmarinic acid and trans-cinnamic acid were analyzed. While nine of them were identified in $C$. pachysporus, eleven of them were identified in S. tenuipes. Fumaric acid was the predominant phenolic compound with a value of $10.62 \pm 0.002 \mu \mathrm{g} / \mathrm{g}$, followed by protocatechuic acid $(2.71 \pm 0.001 \mu \mathrm{g} / \mathrm{g})$ and catechin hydrate $(0.89 \pm 0.001 \mu \mathrm{g} / \mathrm{g})$ in C. pachysporus. The most abundant phenolic compounds in $S$. tenuipes were identified as protocatecheuic acid $(20.50 \pm 0.002$ $\mu \mathrm{g} / \mathrm{g})$, fumaric acid $(4.12 \pm 0.002 \mu \mathrm{g} / \mathrm{g})$ and ellagic acid $(0.58 \pm 0.002 \mu \mathrm{g} / \mathrm{g})$, respectively (Table 1$)$. There is a limited number of studies about identification and quantification of phenolic compounds of Hypogeous Ascomycota truffles in the literature. In previous studies, Villares et al. detected phenolic compounds in Tuber melanosporum, T. aestivum and T. indicum and homogentisic acid were identified as the major phenolic compound in these three truffles. Phenolic compounds of extracts of T. aestivum and T. magnatum were studied and p-hydroxybenzoic acid, protocatechuic acid, and gallic acid were found by Beara et al. In another research, phenolic compounds of extracts of $T$. boudieri were determined as catechin, cinnamic acid, ferulic acid and p-coumaric acid by Doğan and Aydın [22]. The obtained results are consistent with the previous studies.

\subsection{Fatty acid composition}

Fatty acids can regulate lipid metabolism by interacting with enzymes and nuclear transcription factors and affecting mRNA stability. Linoleic acid and linolenic acid are essential fatty acids. The deficiency of daily consumption of essential fatty acids causes in etiology and progression of diseases such as cardiovascular disease and diabetes $[23,24]$. GC and GC/MS were used to analyze fatty acid compositions of $C$. pachysporus and $S$. tenuipes. The results were expressed as percentage of total fatty acids and given in Table 2.

Table 2. The fatty acid compositions of Truffle species (\%)

\begin{tabular}{lll}
\hline Fatty acids & C. pachysporus (\%) & S. tenuipes $(\%)$ \\
Caprylic acid $\left(\mathrm{C}_{8: 0}\right)$ & $\mathrm{nd}$ & 1.04 \\
Nonanoic acid $\left(\mathrm{C}_{9: 0}\right)$ & $\mathrm{nd}$ & 6.71 \\
Pentadecanoic acid $\left(\mathrm{C}_{15: 0}\right)$ & 3.22 & $\mathrm{nd}$ \\
Palmitic acid $\left(\mathrm{C}_{16: 0}\right)$ & $\mathbf{1 6 . 0 1}$ & $\mathbf{3 8 . 6 0}$ \\
Margaric acid $\left(\mathrm{C}_{17: 0}\right)$ & 3.78 & $\mathrm{nd}$ \\
Stearic acid $\left(\mathrm{C}_{18: 0}\right)$ & 4.50 & $\mathbf{1 2 . 2 6}$ \\
Arachidic acid $\left(\mathrm{C}_{20: 0}\right)$ & $\mathrm{nd}$ & 1.24 \\
$\sum$ Saturated fatty acids & 27.51 & 59.85 \\
Palmitoleic acid $\left(\mathrm{C}_{16: 1} \omega 7\right)$ & 4.91 & $\mathrm{nd}$ \\
Oleic acid $\left(\mathrm{C}_{18: 1} \omega 9\right)$ & $\mathbf{1 4 . 5 5}$ & $\mathbf{3 4 . 8 0}$ \\
$\sum$ Monounsaturated fatty acids & 19.46 & 34.80 \\
Linoleic acid $\left(\mathrm{C}_{18: 2} \omega 6\right)$ & $\mathbf{5 3 . 0 3}$ & 5.35 \\
$\sum$ Polyunsaturated fatty acids & 53.03 & 5.35 \\
$\Sigma$ Unsaturated fatty acids & 72.49 & 40.15 \\
$\omega 6 / \omega 9$ & 3.64 & 0.15 \\
\hline
\end{tabular}

$\omega 6 / \omega 9:$ linoleic/oleic acid ratio; nd: not detected

The major fatty acid was found as linoleic acid (53.03\%), followed by palmitic (16.01\%) and oleic acids (14.55\%) in C. pachysporus. Palmitic acid $(38.60 \%)$ was the most abundant fatty acid, followed by oleic $(34.80 \%)$ and stearic acids (12.26\%) in S. tenuipes as seen in Table 2. In earlier studies, fatty acid compositions of Tuber claveryi, T. nivea, $T$. pinoyi, T.boudieri, T. texense and Picoa juniperi truffles were investigated and linoleic (4.13-53.2\%), oleic (3.75-45.90\%), palmitic (8.0-27.87\%) and margaric acids (7.71-18.0\%) were found as the most abundant fatty acids [13, 25-28]. Our findings are similar to previous studies. 


\subsection{Antioxidant activity}

Many studies report that daily antioxidant consumption protects against reactive oxygen species (ROS). Fresh fruits, vegetables, teas and especially edible wild, commercial and culture mushrooms contain the natural antioxidants such as flavonoids, phenolic acids, vitamins, anthocyanins and other phenolic compounds. So they have a protective effect against oxidative damage and diseases by reacting with ROS. In addition to their potential beneficial effects, there has been an increasing demand in pharmaceutical, cosmetic and food industries for the discovery of natural antioxidants compared to synthetic ones such as butylated hydroxytoluene (BHT), butylated hydroxyanisole (BHA), tertbutyl hydroquinone (TBHQ) and gallate (PG), owing to their harmful effects to human health, resulting in carcinogenesis and liver damage $[29,30]$.

The antioxidant activities of the hexane, ethyl acetate, methanol, butanol and water extracts of C. pachysporus and $S$. tenuipes were tested by $\beta$-carotene-linoleic acid, DPPH radical scavenging, ABTS cation radical scavenging, cupricreducing antioxidant capacity (CUPRAC) and metal chelating activity assays. The obtained results and the comparison with the standard compounds i.e. BHA, $\alpha$-tocopherol, and EDTA are shown in Table 3 . The extracts were tested at different concentrations and $\mathrm{IC}_{50}$ values determined. Results were found to be statistically significant $(p<0.05)$ when compared with those of controls in each test. $\beta$-carotene-linoleic acid assay was used to test the antioxidant effect of the extracts of $C$. pachysporus and S. tenuipes. In this test system, peroxy radicals formed from linoleic acid autoxidation cause oxidation and decolourisation of $\beta$-carotene. The presence of the antioxidant in this reaction mixture scavenges radicals and prevents the formation of oxidation [31]. As shown in Table 3, except the hexane extract, all extracts of $C$. pachysporus exhibited higher lipid peroxidation inhibitory activity than $\alpha$-tocopherol. Also, the butanol and water extracts of C. pachysporus exhibited higher lipid peroxidation inhibitory activity than BHA. The butanol extract of $S$. tenuipes showed the highest lipid peroxidation inhibition activity with an $\mathrm{IC}_{50}$ value of $6.25 \pm 0.21 \mu \mathrm{g} / \mathrm{mL}$, followed by methanol ( $\mathrm{IC}_{50}: 7.57 \pm 00.04 \mu \mathrm{g} / \mathrm{mL}$ ) and ethyl acetate extracts $\left(\mathrm{IC}_{50}: 8.77 \pm 0.17 \mu \mathrm{g} / \mathrm{mL}\right.$ ). In general, butanol extracts of truffles showed the highest antioxidant activity among the other extracts.

$\mathrm{DPPH}^{*}$ and $\mathrm{ABTS}^{\bullet+}$ radicals were used to measure free radical scavenging activity of the extracts of truffles. The $\mathrm{DPPH}^{\circ}$, a purple stable free radical, enters the reaction with radicals, electrons or hydrogen atoms and loses color at $515 \mathrm{~nm}$. The ABTS ${ }^{++}$is formed using a potassium persulphate as an oxidizing agent and loses its color in the presence of radical antioxidant [32]. The radical scavenging activity results are presented in Table 3, In DPPH• assay, all extracts of C. pachysporus showed high activity while all extract of $S$. tenuipes displayed low

Table 3. Antioxidant activity of the extracts of Truffle species by $\beta$-Carotene-linoleic acid, DPPH, ABTS, CUPRAC and metal chelating assays ${ }^{\mathrm{a}}$

\begin{tabular}{|c|c|c|c|c|c|c|}
\hline \multicolumn{7}{|c|}{ Antioxidant Activity } \\
\hline & & $\begin{array}{l}\beta \text {-Carotene-linoleic } \\
\text { acid assay }\end{array}$ & $\mathrm{DPPH}^{\bullet}$ assay & $\mathrm{ABTS}^{++}$assay & CUPRAC assay & $\begin{array}{l}\text { Metal chelating } \\
\text { assay }\end{array}$ \\
\hline Truffle species & Extract & $\mathrm{IC}_{50}(\mu \mathrm{g} / \mathrm{mL})$ & $\mathrm{IC}_{50}(\mu \mathrm{g} / \mathrm{mL})$ & $\mathrm{IC}_{50}(\mu \mathrm{g} / \mathrm{mL})$ & $A_{050}(\mu \mathrm{g} / \mathrm{mL})^{\mathrm{c}}$ & Inhibition $\%^{\mathrm{b}}$ \\
\hline \multirow{5}{*}{ C. pachysporus } & Hexane & $2.55 \pm 0.12$ & $52.63 \pm 0.01$ & $37.51 \pm 0.43$ & $38.75 \pm 0.31$ & $21.49 \pm 0.09$ \\
\hline & Ethyl acetate & $2.08 \pm 0.56$ & $53.54 \pm 0.06$ & $35.79 \pm 0.22$ & $23.21 \pm 0.07$ & $42.27 \pm 0.68$ \\
\hline & Methanol & $1.77 \pm 0.23$ & $70.92 \pm 0.41$ & $37.99 \pm 0.09$ & $61.68 \pm 0.14$ & $25.08 \pm 0.59$ \\
\hline & Butanol & $0.51 \pm 0.05$ & $61.28 \pm 0.53$ & $38.50 \pm 0.18$ & $53.75 \pm 0.61$ & $19.85 \pm 0.86$ \\
\hline & Water & $0.48 \pm 0.10$ & $58.51 \pm 0.29$ & $34.52 \pm 0.37$ & $155.55 \pm 0.22$ & $35.72 \pm 0.85$ \\
\hline \multirow{5}{*}{ S. tenuipes } & Hexane & $12.83 \pm 0.83^{\mathrm{b}}$ & $2.56 \pm 0.31^{b}$ & $9.26 \pm 0.74^{b}$ & $286.51 \pm 0.33$ & $78.62 \pm 0.15$ \\
\hline & Ethyl acetate & $8.77 \pm 0.17$ & $5.39 \pm 0.0 .24^{\mathrm{b}}$ & $28.31 \pm 0.45^{\mathrm{b}}$ & $227.41 \pm 0.75$ & $6.06 \pm 0.31$ \\
\hline & Methanol & $7.57 \pm 0.04$ & $12.55 \pm 0.48^{b}$ & $170.93 \pm 0.49$ & $263.55 \pm 0.12$ & $42.76 \pm 0.18$ \\
\hline & Butanol & $6.25 \pm 0.21$ & $17.14 \pm 0.18^{\mathrm{b}}$ & $62.75 \pm 0.31$ & $181.57 \pm 0.09$ & $37.53 \pm 0.34$ \\
\hline & Water & $13.54 \pm 0.32$ & $41.03 \pm 0.88^{\mathrm{b}}$ & $40.22 \pm 0.26$ & $242.50 \pm 0.47$ & $73.81 \pm 0.37$ \\
\hline \multirow{3}{*}{ Standards } & a-Tocopherol ${ }^{d}$ & $2.10 \pm 0.08$ & $37.20 \pm 0.41$ & $38.51 \pm 0.54$ & $66.72 \pm 0.81$ & $\mathrm{NT}^{\mathrm{e}}$ \\
\hline & $\mathrm{BHA}^{\mathrm{d}}$ & $1.34 \pm 0.04$ & $19.80 \pm 0.36$ & $11.82 \pm 0.09$ & $24.40 \pm 0.69$ & $\mathrm{NT}^{\mathrm{e}}$ \\
\hline & EDTA $^{\mathrm{d}}$ & $\mathrm{NT}^{\mathrm{e}}$ & $\mathrm{NT}^{\mathrm{e}}$ & $\mathrm{NT}^{\mathrm{e}}$ & $\mathrm{NT}^{\mathrm{e}}$ & $94.21 \pm 0.41$ \\
\hline
\end{tabular}

a: $\mathrm{IC}_{50}$ values represent the means \pm SEM of three parallel measurements $(p<0.05)$.

b: \% inhibition of $200 \mu \mathrm{g} / \mathrm{mL}$ concentration of truffle extracts.

$c: A_{0.50}$ values represent the means \pm SEM of three parallel measurements $(p<0.05)$.

d:Reference compounds.

e:NT: not tested. 
activity (Table 3 ). In the ABTS ${ }^{\bullet+}$ assay, all studied extracts of $C$. pachysporus displayed higher radical scavenging activity than $\alpha$-tocopherol $\left(\mathrm{IC}_{50}: 38.51 \pm 0.54 \mu \mathrm{g} / \mathrm{mL}\right)$ used as a standard. The water extract of $S$. tenuipes exhibited the highest activity with the $\mathrm{IC}_{50}$ value of $40.22 \pm 0.26$ $\mu \mathrm{g} / \mathrm{mL}$ and followed by methanol $\left(\mathrm{IC}_{50}: 62.75 \pm 0.31 \mu \mathrm{g} /\right.$ $\mathrm{mL}$ ). In both studied truffles, water extracts showed the highest radical scavenging activity. The water of truffles is important in treatment of eyes infections without sideeffects as Prophet Muhammed (Peace Be Upon Him) mentioned in the prophetic medicine [33].

The reducing ability of the extracts of truffles was determined by CUPRAC assay. In this assay, the extracts or standard antioxidants are mixed with $\mathrm{CuSO}_{4}$ and neocuproine, the absorbance is measured at $450 \mathrm{~nm}$. $\mathrm{Cu}$ (II) is reduced to $\mathrm{Cu}$ (I) with the electron-donating antioxidants. The reducing power of the extracts of C. pachysporus were decreased in the order of ethyl acetate $>$ hexane $>$ butanol $>$ methanol $>$ water. Even as the ethyl acetate extract $\left(A_{0.50}: 23.21 \pm 0.07 \mu \mathrm{g} / \mathrm{mL}\right)$ showed higher reducing power than $\alpha$-tocopherol and BHA, all extracts of except water extract exhibited higher reducing power than a-tocopherol. All extracts of $S$. tenuipes showed less activity than standard antioxidants (Table 3).

Electron donating activities of the truffles extracts were measured by reduction of iron ions. The yellow color of the solution turns into blue color at a rate varying according to the reduction effect of the sample. Antioxidants reduce $\mathrm{Fe}^{3+} /$ Ferric cyanide complex to ferrous form and Perl's Prussian blue color of the $\mathrm{Fe}^{2+}$ complex is measured by spectrophotometrically [34]. As seen in Table 3, the results are given as inhibition $\%$ of $200 \mu \mathrm{g} / \mathrm{mL}$ concentration of truffle extracts and compared with EDTA as a standard. The highest metal chelating activity was observed in ethyl acetate $(42.27 \pm 0.68 \%)$ and water extracts $(35.72 \pm 0.85 \%)$ of C. pachysporus among all extracts. The hexane and water extracts of $S$. tenuipes showed the highest metal chelating activity with inhibition values of $78.62 \pm 0.15 \%$ and $73.81 \pm 0.37 \%$, respectively.

The obtained results support the previous studies about antioxidant activity of truffles [18, 19, 22, 28, 35].

\subsection{Anticholinesterase activity}

Alzheimer's disease (AD) is a neurodegenerative disorder associated with progressive age-related and causing loss of memory and cognitive abilities. Using of inhibitors of acetylcholinesterase (AChE) and butyrylcholinesterase (BChE) is the most commonly used method for the treatment of $\mathrm{AD}$. Researchers show great interest in investigating useful phytochemicals from natural sources with low toxicity that inhibits AChE and BChE. Table 4 summaries the acetylcholinesterase (AChE) and butyrylcholinesterase (BChE) inhibitory activities of the extracts of C. pachysporus and S. tenuipes. Against AChE enzyme, all of the extracts of $C$. pachysporus indicated low activity, as for $S$. tenuipes, except for hexane extract; other extracts were found to be inactive. The hexane $\left(\mathrm{IC}_{50}\right.$ : $10.55 \pm 0.13 \mu \mathrm{g} / \mathrm{mL})$, methanol $\left(\mathrm{IC}_{50}: 13.21 \pm 0.50 \mu \mathrm{g} / \mathrm{mL}\right)$ and water extracts $\left(\mathrm{IC}_{50}: 20.48 \pm 0.27 \mu \mathrm{g} / \mathrm{mL}\right)$ of C. pachysporus showed higher inhibitory activity against $\mathrm{BChE}$ enzyme when compared with galantamine ( $\mathrm{IC}_{50}: 50.80 \pm 0.93 \mu \mathrm{g} / \mathrm{mL}$ ) used as a standard. The hexane, ethyl acetate and methanol extracts of $S$. tenuipes exhibited moderate inhibitory activity against BChE enzyme.

Table 4. Anticholinesterase activities of the extracts of Truffle species ${ }^{\mathrm{a}}$

\begin{tabular}{|c|c|c|c|}
\hline Truffle species & Extract & $\begin{array}{c}\text { AChE assay } \\
\mathrm{IC}_{50}(\mu \mathrm{g} / \mathrm{mL})\end{array}$ & $\begin{array}{c}\text { BChE assay } \\
\mathrm{IC}_{50}(\mu \mathrm{g} / \mathrm{mL})\end{array}$ \\
\hline \multirow{5}{*}{ C. pachysporus } & Hexane & $94.75 \pm 0.63$ & $10.55 \pm 0.13$ \\
\hline & Ethyl acetate & $6.90 \pm 0.21^{b}$ & $66.01 \pm 0.98$ \\
\hline & Methanol & $4.05 \pm 0.04^{b}$ & $13.21 \pm 0.50$ \\
\hline & Butanol & $2.29 \pm 0.31^{b}$ & $99.92 \pm 0.15$ \\
\hline & Water & $22.88 \pm 0.09^{\mathrm{b}}$ & $20.48 \pm 0.27$ \\
\hline \multirow{5}{*}{ S. tenuipes } & Hexane & $118.85 \pm 0.11$ & $84.55 \pm 0.41$ \\
\hline & Ethyl acetate & $\mathrm{NA}^{\mathrm{c}}$ & $188.25 \pm 0.99$ \\
\hline & Methanol & $\mathrm{NA}^{\mathrm{c}}$ & $131.16 \pm 0.28$ \\
\hline & Butanol & $\mathrm{NA}^{\mathrm{c}}$ & $>200$ \\
\hline & Water & $\mathrm{NA}^{\mathrm{c}}$ & $\mathrm{NA}^{\mathrm{c}}$ \\
\hline Standards & Galantamine $\mathrm{d}^{\mathrm{d}}$ & $5.00 \pm 0.13$ & $50.80 \pm 0.93$ \\
\hline \multicolumn{4}{|c|}{$\begin{array}{l}\mathrm{a}: \mathrm{IC}_{50} \text { values represent the means } \pm \text { standard deviation of three paralle } \\
\text { measurements }(p<0.05) . \\
{ }^{b}: \% \text { inhibition of } 200 \mu \mathrm{g} / \mathrm{mL} \text { concentration of truffle extracts. } \\
\mathrm{c}: \text { NA: not active } \\
{ }^{\mathrm{d}} \text { : Reference compounds. }\end{array}$} \\
\hline
\end{tabular}

\section{CONCLUSION}

This is the first comprehensive study related to antioxidant and anticholinesterase activities of $C$. pachysporus and $S$. tenuipes with phenolic and fatty acid compositions. Both studied truffles were found to be rich in phenolic and fatty acids. All studied extracts of C. pachysporus displayed higher antioxidant activity than standard, a-tocopherol in $\beta$-carotene-linoleic acid, ABTS cation radical scavenging and cupric-reducing antioxidant capacity (CUPRAC) assays. In anticholinesterase activity, the hexane, methanol and water extracts of C. pachysporus exhibited higher inhibitory activity against BChE enzyme when compared that of galantamine.

According to the results of our study, truffle extracts can be a new source of antioxidant and anticholinesterase drugs. Further investigation about the isolation and identification of the bioactive compounds of C. pachysporus and S. tenuipes are important to explore potential therapeutic effects in more details. 


\section{MATERIALS AND METHODS}

\subsection{Truffle materials and Extraction}

C. pachysporus and S. tenuipes were collected from Muğla, Turkey in 2015. Voucher specimens were deposited at the herbarium of Natural Products Laboratory of Muğla Sitkı Koçman University. Each Truffle species were extracted separately with different solvents (2.5 L) i.e. hexane, ethyl acetate, methanol, butanol, and water at room temperature for $24 \mathrm{~h}$ and four times. Solvents were evaporated on a rotary evaporator to obtain hexane, ethyl acetate, methanol, butanol, and water extracts. All extracts were stored at $+4^{\circ} \mathrm{C}$ until analysis.

\subsection{Analysis of phenolic compounds}

The phenolic compounds analysis was performed by the method of Barros et al. [36] with slight modification. The truffle samples ( $3 \mathrm{~g}$ ) were extracted with acetone: water (80:20 $\mathrm{v} / \mathrm{v} ; 30 \mathrm{~mL}$ ) at $-18{ }^{\circ} \mathrm{C}$ for $24 \mathrm{~h}$. After ultrasonic bath for 15 min, the truffle extract was centrifuged at $4000 \mathrm{rpm}$ for 10 min and filtered through Whatman no. 4 paper. The residue was then re-extracted by two additional $30 \mathrm{~mL}$ of the acetone: water. The combined extracts were evaporated at $40{ }^{\circ} \mathrm{C}$ under reduced pressure to remove acetone. The obtained extract solved in water: methanol (80:20) and filtered through a 0.20 $\mu \mathrm{m}$ disposable LC filter disk for HPLC-DAD. All analysis conditions were identical to those described in the recent publication [8]. The phenolic compounds were characterized according to their retention times, and UV data were compared with commercial standards. Three parallel analyses were performed. For the quantitative analysis of phenolic compounds, calibration curves were obtained via the injection of known concentrations $(0.0,0.00782,0.01563,0.03125$, $0.0625,0.125,0.25,0.5$ and $1.0 \mathrm{ppm}$ ) of different standard compounds i.e. gallic acid, fumaric acid, protocatechuic acid, catechin hydrate, p-hydroxybenzoic acid, 6,7-dihydroxy coumarin, caffeic acid, vanilin, 2,4-dihydroxy benzoic acid, p-coumaric acid, ferulic acid, coumarin, trans-2-hydroxy cinnamic acid, ellagic acid, rosmarinic acid, trans-cinnamic acid. The results were expressed as $\mu \mathrm{g}$ per $\mathrm{g}$ of dry weight $(\mathrm{dw})$.

\subsection{Analysis of fatty acids}

The n-hexane extract was dissolved in $0.5 \mathrm{M} \mathrm{NaOH}(2 \mathrm{~mL})$ in a $25 \mathrm{~mL}$ flask. After the flask was heated in a water bath $\left(50^{\circ} \mathrm{C}\right)$, then $2 \mathrm{~mL} \mathrm{BF}_{3}: \mathrm{MeOH}$ was added. The mixture was boiled for 2 minutes, and then the mixture was left until it cooled down, and then the volume was completed to $25 \mathrm{~mL}$ with saturated $\mathrm{NaCl}$ solution. Esters were extracted with n-hexane; thus, the organic layer was separated. The hexane layer was washed with a potassium bicarbonate solution $(4 \mathrm{~mL}, 2 \%)$ and dried with anhydrous $\mathrm{Na}_{2} \mathrm{SO}_{4}$ and filtered. The organic solvent was removed under reduced pressure by a rotary evaporator to give methyl esters of fatty acid. Derivatization of methyl esters of fatty acids was performed according to the previous method [37]. Qualitative and quantitative analysis of the fatty acid esters were carried out by GC and GC/MSD as reported previously [38].

\subsection{Antioxidant activity}

The total antioxidant activity was evaluated using $\beta$-carotene-linoleic acid test system as previously reported in the literature [39]. The free radical scavenging activity was determined spectrophotometrically by the $\mathrm{DPPH} \cdot$ assay described by Blois [40] with slight modifications [39]. The spectrophotometric analysis of $\mathrm{ABTS}^{\bullet+}$ scavenging activity was performed according to the method of Re et al.[41] with slight modifications [39]. The cupric reducing antioxidant capacity was determined according to the method of Apak et al. [42] with slight modifications [39]. The metal chelating activity of the extracts on $\mathrm{Fe}^{2+}$ was measured using the method described in the literature [43].

\subsection{Anticholinesterase activity}

Acetylcholinesterase and butyrylcholinesterase inhibitory activities were measured by the spectrophotometric method developed by Ellman et al. [43] with slight modifications [39]. Galantamine was used as reference compound. The $\mathrm{IC}_{50}$ values of the extracts were calculated using a program developed from the graph of anticholinesterase inhibitory activity percentages (Inhibition \%) against sample concentrations $(\mu \mathrm{g} / \mathrm{mL})$.

\subsection{Determination of IC50 values and A0.50 values}

The results are given as $50 \%$ inhibition concentration $\left(\mathrm{IC}_{50}\right)$ in $\beta$-carotene-linoleic acid, $\mathrm{DPPH}^{\cdot}$ and $\mathrm{ABTS}^{*}$. Sample concentrations that showed $50 \%$ activity $\left(\mathrm{IC}_{50}\right)$ were calculated from the plot \% activity vs sample concentration. The sample concentration having 0.50 absorbance $\left(\mathrm{A}_{0.50}\right)$ was calculated from the plot of CUPRAC absorbance against sample concentration.

\subsection{Statistical analysis}

All data on antioxidant and anticholinesterase activity tests were the average of triplicate analyses. Data were recorded as mean \pm S.E.M. Significant differences between means were determined by student's- $t$ test, $p$ values $<0.05$ were regarded as significant.

\section{Authorship statement}

Author contributions: Concept -G.TÇ., M.E.D.; Design -G.TÇ., M.E.D.; Supervision -G.TÇ., M.E.D.; Resource 
- G.TC.., M.E.D.; Materials - G.TC.., F.C.., M.E.D.; Data Collection and/or Processing -G.TÇ., E.D., F.Ç.; Analysis and/or Interpretation -G.TÇ., E.D., F.Ç.; Literature Search -G.TÇ., E.D., F.Ç.; Writing -G.TÇ., E.D.; Critical Reviews -G.TÇ., E.D., F.Ç., M.E.D.

\section{Conflict of interest statement}

The authors declared no conflict of interest in the manuscript.

\section{REFERENCES}

[1] Cho IH, Kim SY, Choi H-K, Kim YS. Characterization of aroma-active compounds in raw and cooked pine-mushrooms (Tricholoma matsutake Sing.) J Agric Food Chem. 2006; 54(17): 6332-6335.

[2] Li W, Gu Z, Yang Y, Zhou S, Liu Y, Zhang J. Non-volatile taste components of several cultivated mushrooms. Food Chem. 2014; 143: 427-431.

[3] Naknaen P, Itthisoponkul T, Charoenthaikij P. Proximate compositions, nonvolatile taste components and antioxidant capacities of some dried edible mushrooms collected from Thailand. J Food Measure Character. 2015; 9(3): 259-268.

[4] Heleno SA, Barros L, Martins A, Morales P, FernandezRuiz V, Glamoclija J, Sokovic M, Ferreira ICFR. Nutritional value, bioactive compounds, antimicrobial activity and bioaccessibility studies with wild edible mushrooms. LWTFood Sci Technol. 2015; 63(2): 799-806.

[5] Sharma SK, Gautam N. Evaluation of nutritional, nutraceutical, and antioxidant composition of eight wild culinary mushrooms (Higher Basidiomycetes) from the Northwest Himalayas. Int J Med Mushroom. 2016; 18(6): 539-546.

[6] Sliva D, Jedinak A, Kawasaki J, Harvey K, Slivova V. Phellinus linteus suppresses growth, angiogenesis and invasive behavior of breast cancer cells through the inhibition of AKT signaling. Br J Cancer. 2008; 98: 1348-1356.

[7] Ferreira ICFR, Vaz JA, Vasconcelos MH, Martins A. Compounds from wild mushrooms with antitumor potential. Anticancer Agents Med Chem. 2010; 10(5): 242-436.

[8] Tel-Çayan G, Öztürk M, Duru ME, Rehman M, Adhikari A, Türkoglu A, Choudhary MI. Phytochemical investigation, antioxidant and anticholinesteraseactivities of Ganoderma adspersum. Ind Crop Prod. 2015; 76: 749-754.

[9] Türkoğlu A, Castellano MA. New records of truffle fungi (Basidiomycetes) from Turkey. Turk J Bot. 2013; 37: 970-976.

[10] Bunyard BA. Truffles and False Truffles: A Primer. Fungi 2008; 1: 13-15.

[11] Stanikunaite R, Trappe JM, Khan SI, Rossu SA. Evaluation of therapeutic activity of hypogeous Ascomycetes and Basidiomycetes from North America. Int J Med Mushrooms. 2007; 9(1): 7-14.

[12] Wang S, Marcone MF. The biochemistry and biological properties of the world's most expensive underground edible mushroom: Truffles. Food Res Int. 2011; 44(9): 2567-2581.
[13] Bokhary HA, Suleıman AAA, Basalah MO. The fatty acid components of the desert truffle "al kamah" of Saudi Arabia. J Food Protect. 1989; 52(9): 668-669.

[14] Hussan G, Al-Ruqaie IM. Occurrence in chemical composition, and nutritional value of truffles: Overview. Pak J Biol Sci. 1999; 2(2): 510-514.

[15] Janakat S, Al-Fakhiri S, Sallal AK. A promising peptide antibiotic from Terfezia claveryi aqueous extract against Staphylococcus aureus in vitro. Phytother Res. 2004; 18(10): 810-813.

[16] Fratianni F, Di Luccia A, Coppola R, Nazzaro F. Mutagenic and antimutagenic properties of aqueous and ethanolic extracts from fresh and irradiated Tuber aestivum black truffle: A preliminary study. Food Chem. 2007; 204(2): 471-474.

[17] Janakat S, Nassar M. Hepatoprotective activity of desert truffle (Terfezia claveryi) in comparison with the effect of Nigella sativa in the rat. Pak J Nutr. 2010; 9(1): 52-56.

[18] Beara IN, Lesjak MM, Cetojević-Simin DD, Marjanović ZS, Ristić JD, Mrkonjić ZO, Mimica-Dukić NM. Phenolic profile, antioxidant, anti-inflammatory and cytotoxic activities of black (Tuber aestivum Vittad.) and white (Tuber magnatum Pico) truffles. Food Chem. 2014; 165: 460-466.

[19] Hamza A, Zouari N, Zouari S, Jdir H, Zaidi S, Gtari M, Neffati M. Nutraceutical potential, antioxidant and antibacterial activities of Terfezia boudieri Chatin, a wild edible desert truffle from Tunisia arid zone. Arab J Chem. 2016; 9(3): 383-389.

[20] Anantharaju PG, Gowda PC, Vimalambike MG, Madhunapantula SV. An overview on the role of dietary phenolics for the treatment of cancers. Nutr J. 2016; 15: 99.

[21] Villares A, Garci'a-Lafuente A, Guillamo'n E, Ramos A. Identification and quantification of ergosterol and phenolic compounds occurring in Tuber spp. Truffles. J Food Comp Anal. 2012; 26(1-2): 177-182.

[22] Doğan HH, Aydin S. Determination of antimicrobial effect, antioxidant activity and phenolic contents of desert truffle in Turkey. Afr J Tradit Complement Altern Med. 2013; 10(4): 52-58.

[23] Jonathan JEB. A critical review of methods used to estimate linoleic acid $\Delta 6$-desaturation ex vivo and in vivo. Eur J Lipid Sci Technol. 2005; 107: 119-134.

[24] Yllmaz N, Türkekul I, Bulut S, Sahin F, Bayrak ÖF. Fatty acid composition in ten mushroom species collected from middle black sea region of Turkey. Asian J Chem. 2013; 25(3): 1216-1220.

[25] Bokhary HA, Parvez S. Chemical composition of desert truffless Terfezia claveryi. J Food Compos Anal. 1993; 6(3): 285-293.

[26] Beuchat LR, Brenneman TB, Dove CR. Composition of the pecan truffle (Tuber texense). Food Chem. 1993; 46(2): 189192.

[27] Murcia MA, Mart'inez-Tome M, Vera A, Morte A, Gutierrez A, Honrubia M, Jime' nez AM. Effect of industrial processing on desert truffles Terfezia claveryi Chatin and Picoa juniperi Vittadini): proximate composition and fatty acids. J Sci Food Agric. 2003; 83(6): 535-541.

[28] Stojković D, Reis FS, Ferreira ICFR, Barros L, Glamočlija J, Ćirić A, Nikolić M, Stević T, Giveli A, Soković M. Tirmania 
pinoyi: Chemical composition, in vitro antioxidant and antibacterial activities and in situ control of Staphylococcus aureus in chicken soup. Food Res Int. 2013; 53(1): 56-62.

[29] Bilal S, Khan AL, Waqas A, Shahzad R, Kim I-D, Lee I-J, Shin D-H. Biochemical constituents and in vitro antioxidant and anticholinesterase potential of seeds from native korean persimmon genotypes. Molecules 2016; 21(7): 893.

[30] Klimczak I, Małecka M, Szlachta M, Gliszczy'nska- 'Swigło A. Effect of storage on the content of polyphenols, vitamin C and the antioxidant activity of orange juices. J Food Compos Anal. 2007; 20(3-4): 313-322.

[31] Prior RL, Wu XL, Schaich K. Standardized methods for the de termination of antioxidant capacity and phenolics in foods and dietary supplements. J Agric Food Chem. 2005; 53(10): 4290-4302.

[32] Schaich KM, Tian X, Xie J. Hurdles and pitfalls in measuring antioxidant efficacy: A critical evaluation of ABTS, DPPH, and ORAC assays. J Func Foods. 2015; 14: 111-125.

[33] Owaid MN. Bioecology and uses of desert truffles (Pezizales) in Middle Eastern. Walailak J Sci \& Tech 2018; 15.

[34] [34]Khan RA, Khan MR, Sahreen S, Ahmed M. Evaluation of phenolic contents and antioxidant activity of various solvent extracts of Sonchus asper (L.) Hill. Chem Cent J. 2012; 6: 12.

[35] Al-Laith AAA. Antioxidant components and antioxidant/ antiradical activities of desert truffle (Tirmania nivea) from various Middle Eastern origins. J Food Comp Anal. 2010; 23(1): 15-22.

[36] Barros L, Duenas M, Ferreira ICFR, Baptista P, Santos-Buelga C. Phenolic acids determination by HPLC-DAD-ESI/MS in sixteen different Portuguese wild mushrooms species. Food Chem Toxicol. 2009; 47(6): 1076-1079.
[37] Tel G, Ozturk M, Duru ME, Dogan B, Harmandar M. Fatty acid composition, antioxidant, anticholinesterase and tyrosinase inhibitory activities of four Serratula species from Anatolia. Rec Nat Prod. 2013; 7(2): 86-95.

[38] Ozturk M, Tel G, Ozturk FA, Duru ME. The cooking effect on two edible mushrooms in Anatolia: Fatty acid composition, total bioactive compounds, antioxidant and anticholinesterase activities. Rec Nat Prod. 2014; 8(2): 189-194.

[39] Tel G, Apaydın M, Duru ME, Öztürk M. Antioxidant and cholinesterase inhibition activities of three Tricholoma species with total phenolic and flavonoid contents: The edible mushrooms from Anatolia. Food Anal Method. 2012; 5(3): 495-504.

[40] Blois MS. Antioxidant determinations by the use of a stable free radical. Nature 1958; 181: 1199-1200.

[41] Re R, Pellegrini N, Proteggente A, Pannala A, Yang M, RiceEvans C. Antioxidant activity applying an improved ABTS radical cation decolorization assay. Free Radical Biol Med. 1999; 26(9-10): 1231-1237.

[42] Apak R, Güçlü K, Özyürek M, Karademir SE. Novel total antioxidant capacity index for dietary polyphenols and vitamins $\mathrm{C}$ and $\mathrm{E}$, using their cupric ion reducing capability in the presence of neocuproine: CUPRAC Method. J Agr Food Chem. 2004; 52(26): 7970-7981.

[43] Çayan F, Tel G, Duru ME, ÖztürkM, Türkoğlu A, Harmandar M. Application of GC, GC-MSD, ICP-MS and spectrophotometric methods for the determination of chemical composition and in vitro bioactivities of Chroogomphus rutilus: The edible mushroom species. Food Anal Method. 2014; 7(2): 449-458.

[44] Ellman GL, Courtney KD, Andres V, Featherston RM. A new and rapid colorimetric determination of acetylcholinesterase activity. Biochem Pharmacol. 1961; 7(2): 88-95. 